Analisis Perilaku Brand Switcing Konsumen ...(Dimas Dan Muchammad Agung)

\title{
Analisis Perilaku Brand Switcing Konsumen Produk Air Mineral Di Wilayah Kabupaten Banjarnegara
}

\author{
Dimas Bayu Arianto \\ Universitas Muhammadiyah Purwokerto
}

Muchammad Agung Miftahuddin

Universitas Muhammadiyah Purwokerto

\begin{abstract}
This study aims to determine the effect of free variable price, inconvenience, core service failure, service encounter failure, response to service, attraction by competitors, ethical problems, and involuntary switching to switching behavior of mineral water brand in the region Banjamegara both partially and simultaneously. And to determine the independent variables that most influence on switching behavior of mineral water in the Banjarnegara.

The method used in sampling is purposive sampling, the sampling is based on specific criteria and goals, with criteria respondents who are buying it either weekly or monthly at the distributor or the same store and was in the region Banjamegara. The analytical method used was multiple linear regression test with a significant level (a) 0,1 and the elasticity test.

The results of this study concluded that prices, core service failures, service encounter failures and ethical problems are partially no effect on brand switching, with a significant value of 0,838, 0,925, 0,239 and 0,329 more than 0,1. But attraction by competitor and involuntary switching partially significant effect

on brand switching, with a significant value of 0,070 and 0,087 is less than 0,1 . price, inconvenience, core service failure, service encounter failure, response to service, attraction by competitors, ethical problems, and involuntary switching simultaneously had no effect on brand switching, with a value significantly by

0,141 more than 0,1. involuntary switching variables that most influence on brand switching. This is indicated by the value of E8 > E1, E3, E4, E6 and E7 is $0275>0,018,-0,009,0,153$, 0,176 and $-0,111$.
\end{abstract}

Key words: Price, Inconvenience, Core Service Failure, Service Encounter Failure, Response To Service, Attraction By Competitors, Ethical Problems, Involuntary Switching and Brand Switching.

\section{PENDAHULUAN}

Kebutuhan masyarakat akan air minum sangat tinggi, padahal ketersediaan air yang layak minum dalam arti berkualitas dan terjamin dari segi kesehatan semakin sulit diperoleh. Bisnis air minum mineral semakin menggiurkan, karena kebutuhan akan air minum terus meningkat seiring dengan pertumbuhan penduduk perusahaan yang menggarap bisnis air minum mineral pun semakin banyak dan terus melakukan ekspansi untuk memperluas jaringan pasar produkproduknya. Saat ini masyarakat, terutama di kota-kota tidak bisa lagi lepas dari air minum mineral.

Perilaku variety seeking menurut Kahn, Kalwam dan Morrison yang dikutip oleh (Kahn 1998) disebut juga sebagai kecenderungan individu-individu untuk mencari keberagaman dalam memilih jasa atau barang pada suatu waktu yang timbul karena beberapa alasan yang berbeda. Perilaku ini sering terjadi pada beberapa produk, dimana tingkat keterlibatan produk itu rendah (low involvement). Tingkat keterlibatan produk 
dikatakan rendah, apabila dalam proses pembelian produk konsumen tidak melibatkan banyak faktor dan informasi yang harus ikut dipertimbangkan.

Perilaku perpindahan merek (brand switching) ini sering terjadi pada pemilihan produk dengan tingkat keterlibatan yang rendah Proses pembelian konsumen yang melibatkan pengambilan keputusan khususnya dalam kondisi limited decision making, akan memposisikan konsumen pada situasi untuk berperilaku variety seeking. Pada waktu tingkat keterlibatan konsumen rendah, konsumen akan cenderung untuk berpindah merek, mencari merek lain diluar pasar dan situasi ini menempatkan konsumen dalam sebuah usaha mencari variasi lain.

Pemasar suatu merek akan memposisikan konsumen pada kondisi tetap sesuai dengan kebiasaan (Assael, 1995) apabila merk dari sebuah perusahaan berada dalam posisi pemimpin pasar (market leader), tetapi konsumen kurang memahami betul tentang produk, maka pemasar mempunyai peluang untuk mendukung ke arah terjadinya variety seeking dengan demikian tujuan mempengaruhi konsumen untuk perilaku perpindahan merek lebih mudah menjadi kenyataan.

Pada penelitian terdahulu yang dilakukan oleh (Sulistyani, 2006) dengan mengambil obyek lokasi penelitian di Daerah Istimewa Yogyakarta, yang melibatkan jumlah responden sebanyak 51 orang. Jumlah variabel bebas yang digunakan sebanyak delapan variabel dengan satu variabel terikat yaitu brand switching menghasilkan kesimpulan bahwa terdapat empat variabel bebas yang secara parsial berpengaruh terhadap brand switching yaitu variabel harga, core service failure, service encounterd failure, dan ethical problems, sedangkan variabel yang lain tidak secara signifikan mempengaruhi perilaku konsumen dalam melakukan perpindahan merek air minum mineral.

Penelitian ini yang merupakan suatu replikasi dari penelitian Sulistiyani, 2006, yang juga menitikberatkan pada faktor-faktor penyebab perpindahan merek yang dilakukan oleh konsumen. Dukungan empiris yang tersedia dalam model ini menggambarkan bahwa harga (price), ketidakenakan (inconvenience), kegagalan inti layanan (core service failure), mengalami kegagalan layanan (service

encounter failure), tanggapan atas layanan (response to service), daya tarik pesaing (attraction by competitor), persoalan-persoalan etis (ethical problems), dan perpindahan tanpa sengaja (involuntary switching) memainkan pesan penting dalam keputusan konsumen untuk pindah atau membeli kembali merek yang sama seperti pembelian sebelumnya. Kondisi yang menjadi alasan dilakukannya replikasi penelitian ini disebabkan oleh adanya beberapa pembelian produk yang berpindah dari satu merek ke merek yang lain pada suatu waktu, sedangkan pembelian yang lain tetap konsisten pada pilihan semula pada setiap pembelian.

Di Kabupaten Banjarnegara pada kurun waktu 2 (dua) tahun terakhir ini usaha air minum mineral galon ini sangat kompetitif, hal ini terbukti dari semakin banyaknya merekmerek air minum galon yang sudah beredar di Banjarnegara. Pada pengambilan sampel awal sejumlah 30 responden yang, menunjukkan bahwa sebagian besar responden masih mempercayakan air minum bermerek Aqua dibanding merek-merek lainnya.

Berdasarkan uraian pada latar belakang di atas, maka penulis mencoba untuk meneliti dan menguraikan masalah tersebut dengan memilih judul "ANALISIS PERILAKU BRAND SWITCHING PRODUK AIR MINUM MINERAL DI WILAYAH KABUPATEN BANJARNEGARA".

\section{TINJAUAN PUSTAKA/ LITERATUR}

1. Tipe perilaku konsumen menurut Hawkins et al (2001)

a. Pengambilan keputusan nominal

Pengambilan keputusan ini berkaitan dengan perilaku pembelian kebiasaan (habitual buying). Dimana hasil dari perilaku ini adalah dengan memilih satu merek (single brand) sebagai pilihan. Munculnya satu merek disebabkan oleh beberapa, kemungkinan, misalnya karena tidak ada pilihan-pilihan merek, dengan kata lain merek yang tersedia untuk kategori produk itu hanya satu merek. Bisa juga karena produk sudah menjadi komoditi, ini terjadi 
pada saat kesamaan lebih menoni ol dibanding perbedaan antar produk maka peran merek akan menjadi lebih kecil.

Kemungkinan lainnya adalah karena loyalitas merek yang tinggi. Loyalitas merek yang tinggi identik dengan brand involvement yang tinggi. Sekali komit dengan suatu merek, tentu setelah merasa merek tersebut memberikan nilai paling tinggi, konsumen tidak akan bersusah-susah mengevaluasi merek-merek yang ada untuk menentukan pilihan.

b. Pengambilan keputusan terbatas

Dalam pengambilan keputusan terbatas (limited decision making) meliputi pencarian informasi secar internal maupun ekstemal terbatas (limited external), sedikit alternatif, aturan pengambilan keputusan sederhana atas sejumlah kecil atribut, dan evaluasi purna pembelian yang rendah.

c. Pengambilan keputusan diperluas

Pengambilan keputusan ini meliputi proses yang melibatkan pencarian informasi internal maupun ekstemal yang intensif, diikuti oleh evaluasi yang kompleks atas sejumlah besar alternatif yang tersedia. Pengambilan keputusan ini biasanya terjadi pada produkproduk yang harganya relatif mahal, jarang dibeli dan resiko tinggi.

Perilaku beralih dapat berasal dari sangat beragamnya penawaran produk lain, atau karena terjadi masalah dengan produk yang sudah dibeli. Switching behavior atau variety seeking didefinisikan sebagai kebebasan memilih yang lebih disukai terhadap sebuah item khusus (Menon dan Khan, 1995). Perilaku beralih dalam memilih merek produk dapat juga diakibatkan karena ketidaktahuan konsumen, dimana harga merupakan sebagian dari banyak faktor yang dapat menyebabkan konsumen beralih ke merek lain. Beberapa konsumen akan ketika ada merek produk baru yang lebih mahal. Hal ini memberi kesan bahwa kualitas produk dinilai dari harganya.

Menurut Dharmmesta (1999) brand switching behavior adalah perilaku perpindahan merek yang dilakukan konsumen karena beberapa alasan tertentu, atau diartikan juga sebagai kerentanan konsumen untuk berpindah ke merek lain.

Penilaian konsumen terhadap merek dapat timbul dari berbagai variabel, seperti pengalaman konsumen dengan produk sebelumnya dan pengetahuan konsumen tentang produk. Pengalaman konsumen dalam memakai produk dapat memunculkan komitmen terhadap merek produk tersebut.

Pengambilan keputusan pembelian suatu produk yang ditawarkan di pasar dapat dipengaruhi oleh konsumen. Dengan adanya stimulus (rangsangan) dari luar yang akan menekan syaraf sensor seseorang melalui kelima indera manusia maka konsumen atau manusia itu akan dapat menimbulkan persepsi.

Persepsi adalah suatu proses dimana individu memilih, merumuskan masukan informasi untuk menciptakan suatu gambaran yang berarti mengenai dunia. (Phillip Kotler dalam Bilson Simamora, 2002).

Berdasarkan uraian diatas maka hipotesis dalam penelitian ini dapat dirumuskan sebagai berikut:

1. Variabel bebas harga (price) secara parsial berpengaruh signifikan terhadap perilaku perpindahan merek air minum mineral di wilayah Banjamegara

2. Variabel bebas ketidakenakan (inconvenience) secara parsial berpengaruh signifikan terhadap perilaku perpindahan merek air minum mineral di wilayah Banjamegara

3. Variabel bebas kegagalan inti layanan (core service failure) secara parsial berpengaruh signifikan terhadap perilaku perpindahan merek air minum mineral di wilayah Banjamegara

4. Variabel bebas mengalami kegagalan layanan (service encounter failure) secara parsial berpengaruh signifikan terhadap perilaku perpindahan merek air minum mineral di wilayah Banjamegara

5. Variabel bebas tanggapan atas layanan (response to service) secara parsial berpengaruh signifikan terhadap perilaku perpindahan merek air minum mineral di wilayah Banjamegara 
6. Variabel bebas daya tarik pesaing (attraction by competitor) secara parsial berpengaruh signifikan terhadap perilaku perpindahan merek air minum mineral di wilayah Banjamegara

7. Variabel bebas persoalan-persoalan etis (ethical problems) secara parsial berpengaruh signifikan terhadap perilaku perpindahan merek air minum mineral di wilayah Banjamegara

8. Variabel bebas perpindahan tanpa sengaja (involuntary switching) secara parsial berpengaruh signifikan terhadap perilaku perpindahan merek air minum mineral di wilayah Banjamegara

9. Variabel bebas harga (price), ketidakenakan (inconvenience), kegagalan inti layanan (core service failure), mengalami kegagalan layanan (service encounter failure), tanggapan atas layanan (response to service), daya tarik pesaing (attraction by competitor), persoalan-persoalan etis (ethical problems), dan perpindahan tanpa sengaja (involuntary switching) secara simultan berpengaruh signifikan terhadap perilaku perpindahan merek air minum mineral di wilayah Banjamegara

10. Variabel bebas involuntary switching mempunyai pengaruh paling besar terhadap perpindahan merek pada konsumen air minum mineral di wilayah Banjarnegara dibandingkan variabel bebas yang lain.

\section{METODOLOGI PENELITIAN}

\section{Populasi dan Sampel}

Penelitian ini dilakukan dengan mempergunakan sampel sebanyak 100 orang (responden) untuk mewakili konsumen air minum mineral di wilayah Kabupaten Banjarnegara. Adapun metode pengambilan sampelnya adalah menggunakan Purposive Sampling, yaitu pengambilan sampel yang berdasarkan pada kriteria dan tujuan tertentu saja (Sugiyono, 2003). Kriteria tersebut adalah responden yang melakukan pembelian secara tetap baik mingguan ataupun bulanan pada distributor atau toko yang sama dan berada di wilayah Kabupaten Banjarnegara.

\section{Definisi Operasional}

a. Variabel Terikat Brand switching $(\mathrm{Y})$

Brand switching adalah perilaku untuk berpindah merek, indikator dalam penelitian ini pembelian ulang air minum mineral dengan merek yang berbeda dengan pembelian sebelumnya, dengan menggunakan item kuesioner.

b. Variabel Bebas Harga (XI)

Harga yang dimaksud dalam penelitian ini adalah strategi penetapan harga produk air minum mineral yang mencakup indikator : harga yang tinggi, kenaikan harga, penetapan harga yang tidak wajar dan praktik penipuan harga

c. Variabel Bebas Inconvenience / ketidakenakan (X2)

Inconvenience / ketidakenakan yaitu semua kejadian kritis dimana konsumen merasa dirugikan dengan indikator lokasi penyedia produk, waktu layanan, menunggu waktu layanan, menunggu waktu membuat janji.

d. Variabel Bebas Core service failure (X3)

Core service failure atau yang disebut dengan kegagalan inti layanan mencakup indikator-indikator : kesalahan dalam layanan, kesalahan dalam pembayaran dan layanan yang membahayakan.

e. Variabel Bebas Service Encounterfailure (X4)

Service Encounter failure adalah kegagalan layanan yang didefinisikan sebagai interaksi antara konsumen dengan perusahaan penyedia produk. Variable ini ditandai dengan indikator-indikator ketidakpedulian karyawan penyedia produk yang meliputi ; tidak peduli, tidak sopan, tidak reaksi dan tidak berpendidikan.

f. Variabel Bebas Employe Responses to Service Failure (X5) 
Analisis Perilaku Brand Switcing Konsumen ...(Dimas Dan Muchammad Agung)

Employe Responses to Service Failure diartikan sebagai kegagalan respon karyawan dalam memberi layanan, dalam penelitian ini menggunakan indikator : keengganan merespon, kegagalan untuk merespon dan respon negatif yang jelas terlihat.

g. Variabel Bebas Attraction by competitor (X6)

Attraction by competitor adalah perilaku daya tarik dari pesaing produk yang sama, dalam penelitian ini menggunakan indikator penelitian produk yang lebih menarik, lebih dapat dipercaya dan menyediakan produk dengan kualitas yang lebih tinggi.

h. Variabel Bebas Ethical Problems (X7)

Ethical Problems dapat diartikan berarti keadaan-keadaan dimana konsumen memandang suatu penyimpangan terhadap permasalahan etis, dalam penelitian ini menggunakan indikator sikap yang tidak jujur, perilaku mengintimidasi, praktik yang tidak aman atau tidak sehat dan konflik kepentingan.

i. Variabel Bebas Involuntari Switching (X8)

Involuntari Switching adalah suatu perilaku konsumen dalam melakukan perpindahan merek produk tanpa sengaja karena diluar jangkauan konsumen atau penyedia jasa, yang dalam penelitian ini digunakan indikator karena perpindahan lokasi penyedia jasa maupun konsumen.

\section{Alat analisis yang digunakan}

Analisis yang digunakan dalam penelitian ini adalah uji regresi linear berganda, dengan persamaan sebagai berikut:

$$
\begin{aligned}
& Y=a+b 1 \times 1+b 2 \times 2+b 3 \times 3+b 4 \times 4+b 5 \times 5+b 6 \times 6+b 7 \times 7+b 8 \times 8 \\
& \text { Keterangan: } \\
& Y \quad: \text { Perilaku (brand switching) perpindahan merek } \\
& a \quad: \text { Konstanta }
\end{aligned}
$$

x1... x8 : Variabel bebas : harga (price), ketidakenakan (inconvenience), kegagalan inti layanan (core service failure), kegagalan layanan (service encounter failure), tanggapan atas layanan (response to service), daya tarik pesaing (attraction by competitor), persoalan-persoalan etis (ethical problems), dan perpindahan tanpa sengaja (involuntary switching)

b1... b8 : Koefisien regresi variabel bebas

\section{HASIL DAN PEMBAHASAN}

\section{Pengujian Hipotesis dan Pembahasan}

Hasil penelitian ini menunjukkan bahwa pengujian validitas dan reliabilitas namun variabel ketidak enakan dan tanggapan atas layanan kurang tidak reliabel dengan demikian variabel ketidak enakan dan tanggapan atas layanan kurang tidak dapat diikutkan dalam analisis selanjutnya. Uji asumsi klasik model regresi sudah terbebas dari permasalahan normalitas, multikolinearitas, autokorelasi dan heteroskedastisitas. Dengan demikian model regresi sudah tepat digunakan dalam pengujian hipotesis dalam penelitian ini.

Berdasarkan analisa dapat disusun persamaan regresi sebagai berikut:

$$
Y=4,268+0,023 X 1-0,010 X 3+0,130 X 4+0,185 X 6-0,102 X 7+0,227 X 8+e
$$

Berdasarkan persamaan regresi tersebut dapat diketahui bahwa jika variabel independen tidak berubah maka brand switching sebesar 4,268 satuan.

Sedangkan koefisien regresi X1 sebesar 0,023 menyatakan bahwa setiap terjadi peningkatan harga satu satuan maka akan terjadi peningkatan brand switching sebesar 0,023 satuan jika variabel independen yang lain tidak berubah.

Koefisien regresi X3 sebesar -0,010 menyatakan bahwa setiap terjadi peningkatan kegagalan inti pelyanan satu satuan maka akan terjadi penurunan brand switching sebesar 0,010 satuan jika variabel independen yang lain tidak berubah. 
Analisis Perilaku Brand Switcing Konsumen ...(Dimas Dan Muchammad Agung)

Koefisien regresi $X 4$ sebesar 0,130 menyatakan bahwa setiap terjadi peningkatan kegagalan pelayanan satu satuan maka akan terjadi peningkatan brand switching sebesar 0,130 satuan jika variabel independen yang lain tidak berubah.

Koefisien regresi X6 sebesar 0,185 menyatakan bahwa setiap terjadi peningkatan kegagalan inti pelayanan satu satuan maka akan terjadi peningkatan brand switching sebesar 0,185 satuan jika variabel independen yang lain tidak berubah.

Koefisien regresi $X 7$ sebesar $-0,102$ menyatakan bahwa setiap terjadi peningkatan persoalan etis satu satuan maka akan terjadi penurunan brand switching sebesar 0,102 satuan jika variabel independen yang lain tidak berubah.

Koefisien regresi $X 8$ sebesar 0,227 menyatakan bahwa setiap terjadi peningkatan pindah tanpa sengaja satu satuan maka akan terjadi peningkatan brand switching sebesar 0,227 satuan jika variabel independen yang lain tidak berubah.

\section{Hipotesis Pertama}

Untuk mengetahui pengaruh Variabel bebas harga (price) secara parsial berpengaruh signifikan terhadap perilaku perpindahan merek air minum mineral di wilayah Banjamegara menggunakan uji t.

Berdasarkan tabel tersebut diketahui bahwa nilai signifian variabel harga sebesar 0,838 lebih dari 0,1 sehingga dapat disimpulkan bahwa harga (price) secara parsial tidak berpengaruh signifikan terhadap perilaku perpindahan merek air minum mineral di wilayah Banjamegara, dengan demikian hipótesis pertama ditolak.

\section{Hipotesis Kedua}

Hipótesis kedua dalam penelitian ini tidak dapat dibuktikan karena variabel ketidakenakkan tidak reliabel.

\section{Hipotesis Ketiga}

Nilai signifian variabel kegagalan inti layanan sebesar 0,925 lebih dari 0,1 sehingga dapat disimpulkan bahwa kegagalan inti layanan secara parsial tidak berpengaruh signifikan terhadap perilaku perpindahan merek air minum mineral di wilayah Banjamegara, dengan demikian hipótesis ketiga ditolak.

\section{Hipotesis Keempat}

Nilai signifian variabel kegagalan layanan sebesar 0,239 lebih dari 0,1 sehingga dapat disimpulkan bahwa kegagalan layanan secara parsial tidak berpengaruh signifikan terhadap perilaku perpindahan merek air minum mineral di wilayah Banjamegara, dengan demikian hipótesis keempat ditolak.

\section{Hipotesis Kelima}

Hipótesis kelima dalam penelitian ini tidak dapat dibuktikan karena variabel ketidakenakkan tidak reliabel.

\section{Hipotesis Keenam}

Nilai signifian variabel daya tarik pesaing sebesar 0,070 kurang dari 0,1 sehingga dapat disimpulkan bahwa daya tarik pesaing secara parsial berpengaruh signifikan terhadap perilaku perpindahan merek air minum mineral di wilayah Banjamegara, dengan demikian hipótesis keenam diterima. 


\section{Hipotesis Ketujuh}

Nilai signifian variabel persoalan etis sebesar 0,329 lebih dari 0,1 sehingga dapat disimpulkan bahwa persoalan etis secara parsial tidak berpengaruh signifikan terhadap perilaku perpindahan merek air minum mineral di wilayah Banjamegara, dengan demikian hipótesis ketujuh ditolak.

\section{Hipotesis Kedelapan}

Nilai signifian variabel pindah tanpa sengaja sebesar 0,087 kurang dari 0,1 sehingga dapat disimpulkan bahwa pindah tanpa sengaja secara parsial berpengaruh signifikan terhadap perilaku perpindahan merek air minum mineral di wilayah Banjamegara, dengan demikian hipótesis kedelapan diterima.

\section{Hipotesis Kesembilan}

Untuk mengetahui pengaruh harga, ketidakenakan, kegagalan inti pelayanan, kegagalan layanan, tanggapan atas layanan, daya tarik pesaing, persoalan-persoalan etis dan pindah tanpa sengaja terhadap brand switching secara simultan dapat dilihat dari hasil uji F.

Berdasarkan hasil analisa diketahui nilai signifikan sebesar 0.141 lebih dari 0.1 . Dengan demikian harga, ketidakenakan, kegagalan inti pelayanan, kegagalan layanan, tanggapan atas layanan, daya tarik pesaing, persoalan-persoalan etis dan pindah tanpa sengaja secara simultan tidak berpengaruh terhadap brand switching, dengan demikian hipotesis kesembilan ditolak.

\section{Hipotesis Kesepuluh}

Untuk menguji hipotesis kedua atau untuk mengetahui apakah Variabel involuntary switching mempunyai pengaruh yang paling dominan terhadap brand switching, menggunakan uji elastisitas. Hasil uji elastisitas dapat dilihat sebagai berikut:

Berdasarkan uji elastisitas dapat diketahui nilai elastisitas variabel harga, kegagalan inti pelayanan, kegagalan layanan, daya tarik pesaing, persoalan-persoalan etis dan pindah tanpa sengaja sebesar $0.018,-0.009,0.153,0.176,-0.111$ dan 0.275 . Sehingga dapat disimpulkan bahwa E8 > E1,E3,E4,E6 dan E7 yaitu $0.275>0.018,-0.009,0.153,0.176$ dan -0.111 dengan demikian hipotesis kesepuluh yang menyatakan variabel bebas involuntary switching mempunyai pengaruh paling besar terhadap perpindahan merek pada konsumen air minum mineral di wilayah Banjarnegara dibandingkan variabel bebas yang lain diterima.

\section{KESIMPULAN DAN SARAN}

\section{Kesimpulan}

Berdasarkan analisis yang telah dilakukan, maka ditarik beberapa kesimpulan, antara lain:

1. Harga (price) secara parsial tidak berpengaruh signifikan terhadap perilaku perpindahan merek air minum mineral di wilayah Banjarnegara. Hal ini ditunjukkan dengan nilai signifikan variabel harga sebesar 0,838 lebih dari 0,1 .

2. Hipótesis kedua dalam penelitian ini tidak dapat dibuktikan karena variable ketidakenakkan tidak reliabel.

3. Kegagalan inti layanan secara parsial tidak berpengaruh signifikan terhadap perilaku perpindahan merek air minum mineral di wilayah Banjarnegara. Hal ini ditunjukkan dengan nilai signifikan sebesar 0,925 lebih dari 0,1.

4. Kegagalan layanan secara parsial tidak berpengaruh signifikan terhadap perilaku perpindahan merek air minum mineral di wilayah Banjarnegara. Hal ini ditunjukkan dengan nilai signifikan sebesar 0,239 lebih dari 0,1.

5. Hipótesis kelima dalam penelitian ini tidak dapat dibuktikan karena variable ketidakenakkan tidak reliabel. 
6. Daya tarik pesaing secara parsial berpengaruh signifikan terhadap perilaku perpindahan merek air minum mineral di wilayah Banjarnegara. Hal ini ditunjukkan dengan nilai signifikan sebesar 0,070 kurang dari 0,1.

7. Persoalan etis secara parsial tidak berpengaruh signifikan terhadap perilaku perpindahan merek air minum mineral di wilayah Banjarnegara. Hal ini ditunjukkan dengan nilai signifikan 0,329 lebih dari 0,1.

8. Pindah tanpa sengaja secara parsial berpengaruh signifikan terhadap perilaku perpindahan merek air minum mineral di wilayah Banjarnegara. Hal ini ditunjukkan dengan nilai signifikan 0,087 kurang dari 0,1.

9. Harga, ketidakenakan, kegagalan inti pelayanan, kegagalan layanan, tanggapan atas layanan, daya tarik pesaing, persoalan-persoalan etis dan pindah tanpa sengaja secara simultan tidak berpengaruh terhadap brand switching. Hal ini ditunjukkan dengan nilai signifikan sebesar 0.141 lebih dari 0.1 .

10. Perpindahan tanpa disengaja merupakan variabel yang paling berpengaruh terhadap brand switching. Hal ini ditunjukkan dengan nilai E8 > E1,E3,E4,E6 dan E7 yaitu $0.275>$ $0.018,-0.009,0.153,0.176$ dan -0.111 .

\section{Saran}

1. Konsumen hendaknya lebih jeli dalam memilih produk sehingga dapat meminimalisir akibat perpindahan merek.

2. Produsen sebaiknya membuat produknya sebaik mungkin dengan cara menjaga rasa tetap enak dan hegienis dan membuat produk semenarik mungkin dengan cara memberi kemasan dan iklan yang baik, sehingga konsumen tidak tertarik denan produk lain dan tidak mencoba produk lain yang dapat mengakibatkan konsumen berpindah merek.

3. Bagi manajemen Rita Pasaraya, penelitian ini bisa dijadikan dasar pertimbangan dalam menggunakan metode pemasaran yang tepat, karena aspek-aspek yang berkaitan dengan kesadaran menjaga kesehatan, kesadaran lingkungan, harga premium, trend keamanan pangan, keterlibatan proses pembelian berpengaruh terhadap niat pembelian produk hijau. Serta dengan menyediakan produk hijau yang lebih banyak sehingga lebih menarik konsumen.

\section{DAFTAR PUSTAKA}

Assael, Henry. 1998. Consumer Behaviour And Marketing Action, South Western College. Pubishing.

Basu Swasta dan Irawan. 2000. Manajemen Pemasaran Modern. Edisi II. Liberty Offset. Yogyakarta.

Bilson Simamora. 2002. Panduan Riset Perilaku Konsumen. PT. Gramedia Pustaka Utama.

Del I Hawkins, Roger J. Best dan Knneth A. Coney. 2001. Consumer Behaviour, Implication For Marketing Strategy. Businness Publications Inc. Texas.

Dharmmesta, B.S dan Handoko, H. 1997. Manajemen Pemasaran, Analisa Prilaku Konsumen. Edisi 2. Liberty. Yogyakarta.

Enggle, Blackwell dan Miniard. 1994. Prilaku Konsumen. Jilid I, Edisi VI. Binarupa Aksara. Jakarta.

Husein, Umar. 2000. Metode Riset Bisnis. PT. Gramedia Pustaka Utama. Jakarta.

Kahn, Barbara E. 1998. Dinamic Relationship With Customers: High Variety Strategies. Journal of The Academy of Marketing Science. Vol. 26. 
Analisis Perilaku Brand Switcing Konsumen ...(Dimas Dan Muchammad Agung)

Keaveney, M.S. 1995. Customer Switching Behaviour in Service Industries: An Exporatory Study. Journal of Marketing.

Kotler, Philip. 1997. Manajemen Pemasaran Analisis Perencanaan, Implementas dan Kontrol. Prentice Hall.

Menon, Satya dan Khan, Barbara E. 1995. The Impact of Context on Variety Seeking in Product Choices. Journal of Consumer Research. Vol. 22. December. P.285-295.

Robert S Pyndick dan Daniel L. Robinfield. 1990. Econometric Models And Economic Forecast. Mac. Growhill Kugikisha Ltd. Japan.

Singarimbun M dan Effendi S. 1995. Metode Penelitian Survei. LP3ES. Jakarta.

Sugiono. 2003. Metode Penelitian Bisnis. CV. Alfabeta. Bandung.

Sulistyani, Tina. 2006. Analisis Perilaku Brand Switching Produk Air Minum Mineral di Daerah Istimewa Yogyakarta. Jurnal Akuntansi dan Manajemen. STIE YKPN. Yogyakarta.

Supranto. J. 2000. Statistik Teori dan Aplikasi. PT. Erlangga. Jakarta.

Willy Sidharta. 2004. Persaingan Air Minum dalam Kemasan AQUA Galon. Kompas. Jakarta. 